\title{
The Role of Human Resource Accounting for Gaining Competitive Advantage
}

\author{
Supriya. Gk \\ Faculty Member, IMSR, Kuvempu University, Shimoga, Karnataka, India
}

\begin{abstract}
Human resource accounting is the accounting methods, systems, and techniques, which coupled with special knowledge and ability, assist personnel management in the valuation of personnel in their knowledge, ability and motivation in the same organization as well as from organization to organization. The Human Resource Audit is an organized official process, which is designed to investigate the strategies, policies, procedures, documentation, structure, systems and practices with respect to the organization's human resource management. Human resource accounting and auditing helps management in identifying, measuring data and to audit human resource capital. Human resource accounting frames policies, procedures and various steps that is required for an organization. It is the measurement of the cost and value of human being to organization. It involves measuring costs incurred by private firms and public sectors to recruit, select, hire, train and develop employees and judge their economic value to the organization. Human resource audit is also a systematic formal process. Human resources are the people in an organization, so a human resources audit is a look at those people and the processes that put them in place to make sure the system is working efficiently. Human resource accounting and auditing are not legally binding in nature. The present paper focuses on the role and importance of Human resource accounting towards business competitiveness. The paper will also highlight the need, , benefits and challenges of Human resource accounting .
\end{abstract}

KEYWORDS: Human Resource Accounting, Human Resource Audit, Human Resource Capital. Human Capital Valuation, Human Resource Investments, Strategic human resource planning

\section{INTRODUCTION}

HRA is one of latest concepts adopted by Indian companies in recent times. The past few decades have witnessed a global transition from manufacturing to service based economies. Human Resource Accounting consists measuring the cost incurred by an organization to recruit, select, hire, train and develop human assets and also involves measuring the economic value of people in the organization. It is concerned with measurement of cost and value of people in the organization.

Human elements are so important input for the success of any corporate enterprise. Human Resource Accounting is a process of identifying and measuring data about human resources. It is very helpful to the management to frame policies for human resources.

Human Resource Audit is a look on overall people and processes that put them in place to make sure the system of working efficiently

Auditing has been a routine exercise in the area of finance, especially because it is a statutory obligation but this is not binding in nature. Some of the companies nevertheless prefer to have Human Resource Audit. . It systematically and scientifically assesses the strength, limitations and developmental needs of the existing human resources from the larger point of view of enhancing organisational performance It helps management to check the gap between current status and desired status in the area that is being audited. It is very helpful to examine the strategies, documentation, systems, policies, structure and practices with respect to the organization's human resource management.

\section{Literature review:}

Randall S. Schuler-Human resource management 1984 Vol 23. No.3, PP-241-255

In his article gaining competitive advantage through HRM practices gave stress towards competitive advantage. Now a day most of the companies came to know that importance of HR and its auditing. The article says that the company can gain the strategic advantage, company can control its own destiny and to the extent it can gain an advantage difficult for competitors to remove stay in control longer. The article also explains the role of management functions in organization performance. The author also lists out the barriers to competitive advantage. Primary and secondary data were used as tool for data collection. At the end author concludes by giving two suggestions that is helping themselves and others is by helping others is shows importance of HR in organization. the second one is; it is better to practice HR auditing in each organization to develop competitive advantage.

David sloan, peter Gregor, paul booth (2002) Interacting with computer Vol.4-313-325

In his article auditing accessibility of higher education website given increasingly important role of world wide website place an important source and yet with continuing problem that certain individual particularly with those disabilities and those using nonstandard web browsing technology. This article discussed development of methodology used to carry out HR audits findings of audit in terms of accessibility level of subject sites and feedback as a result of HR auditing process. Most of accessibility problems are outlined here in this article, primary and secondary data are used so many recommendations like task should be carried out in time etc are given and it is concluded by saying that auditing exercise had immediate positive effect on accessibility of subjects sites. It is hoped that general 
awareness of accessibility issues has been raised among higher education community.

Syed Abdulla Almamun- BRAC university journal. Vol.4, No.1, 2009 PP-35-43.

In his article human resource accounting disclosure of Bangladesh company and its association with corporate characteristics, he made an attempt to study the relationship between corporate characteristics.

Human resource disclosure level in 55 randomly selected companies of Bangladesh, the study is empirical in nature based on primary and secondary source. The author measured HRAR variables and HRADI was computed by using formulas also prepared $\mathrm{Hr}$ disclosure in index. It has been concluded at the end that HR is very important factor for decision makers in the era of knowledge based economy.

Johannes M. pennings, (1998) Academy of management journal vol.41, No.4,425-440"The article Human capital, Social capital and firm dissolution" The article examine the effect of Human and social capital upon firm auditing and dissolution with data from the population of Dutch accounting firms for the period of 1880-1990. Findings suggest an integration of resources based view of the firm and organisational ecology and his stimulant for future resources. The analysis of this paper is based on 1851 firms. The empirical analysis of this study deals with time varying conditions that may explain organization dissolution. This study produced major evidence for contention that a firm human and social capital have important implications for the performance.

\section{OBJECTIVES OF THE STUDY}

A. To know the importance and benefits of human recourse accounting

B. To identify the challenges faced by human resource accounting

C. To know the importance of different methods of human resource accounting to gain competitive advantage in business.

\section{METHODOLOGY}

This study is an empirical study based on secondary data which is collected through googling and from various books, journals and articles published.

\section{HISTORICAL REVIEW OF HUMAN RESOURCE ACCOUNTING}

Determination of effectiveness of people who are working in the organization in financial term called Human Resource Accounting.Human recourse are the greatest assets of every organization. In the decade of 1960, many researchers have developed procedures of accounting for the people who are working in the organization as human resource asset. It is related to the human resource capital and the expenditure of human capital formation is regarded as a charge against the revenue of the period as it does not create any physical asset. But this concept has changed and the cost incurred on any human resource asset should be capitalized as it yields benefits quantifiable in financial terms.

This method tells that the investment made by organization in the people and how the value of these people change over a time. The possession of employee is compared with substitute cost from time to time.

\section{According to Eric G Flamholtz}

\begin{tabular}{|c|c|}
\hline $\begin{array}{l}\text { FIRST STAGE } \\
(1960-1966)\end{array}$ & $\begin{array}{l}\text { Beginning of academic interest in } \\
\text { the area of Human Resource } \\
\text { Accounting }\end{array}$ \\
\hline $\begin{array}{l}\text { SECOND STAGE } \\
(1966-1971)\end{array}$ & $\begin{array}{l}\text { The focus here was more on } \\
\text { developing and validating } \\
\text { different models of Human } \\
\text { Resource Accounting }\end{array}$ \\
\hline $\begin{array}{l}\text { THIRD STAGE } \\
(1971-1976)\end{array}$ & $\begin{array}{l}\text { This period was marked by a } \\
\text { widespread interest in the field of } \\
\text { Human Resource Accounting. R.G. } \\
\text { Barry experiments contributed } \\
\text { substantially during this stage. }\end{array}$ \\
\hline $\begin{array}{l}\text { FOURTH STAGE } \\
(1976-1980)\end{array}$ & $\begin{array}{l}\text { This was the period of decline in } \\
\text { the area of Human Resource } \\
\text { Accounting. }\end{array}$ \\
\hline $\begin{array}{l}\text { FIFTH STAGE } \\
(1980 \\
\text { ONWORDS) }\end{array}$ & $\begin{array}{l}\text { There was a sudden renewal of } \\
\text { interest in the field of Human } \\
\text { Resource accounting }\end{array}$ \\
\hline
\end{tabular}

\section{BENEFITS OF HUMAN RESOURCE ACCOUNTING}

The advantages of using human resource accounting are listed below:

$>$ It increase productivity

$>$ Brings high return

$>$ Help individual employee to aspire

$>$ Provides scope for advancement

$>$ Throws light on the strength and weaknesses of existing workforce

$>$ Helps potential investors to judge a company

\section{MODELS OF HUMAN CAPITAL VALUATION}

Many models are created to add value to human capital. Some are based on historic costs while some are based on future earnings. But every model has its own limitations and one model has proved to be more valid than other. The Lev and Schwartz model has been the most widely used model for its ease of use and convenience.

HRA information disclosed by some of the companies (Based on survey conducted)

\begin{tabular}{|c|c|c|c|}
\hline $\begin{array}{c}\text { Name of the } \\
\text { organization }\end{array}$ & $\begin{array}{c}\text { HRA introduced in } \\
\text { the year }\end{array}$ & $\begin{array}{c}\text { Discount rate } \\
\text { (in \%) }\end{array}$ \\
\hline BHEL & $1973-74$ & Lev \& Schwartz model & 12 \\
\hline SAIL & $1983-84$ & $\begin{array}{c}\text { Lev \& Schwartz model with Some refinements as } \\
\text { suggested by Eric.G. Flamholtz \& Jaggi and Lev }\end{array}$ & 14 \\
\hline MMTC & $1982-83$ & Lev \& Schwartz model & 12 \\
\hline ONGC & $1981-82$ & Lev \& Schwartz model & 12 \\
\hline NTPC & $1984-85$ & Lev \& Schwartz model & 12.96 \\
\hline \multirow{2}{*}{ INFOSYS } & $1995-96$ & Lev \& Schwartz model & 14.97 \\
\cline { 2 - 4 } & $2006-07$ & Lev \& Schwartz model & 16.98 \\
\cline { 2 - 4 }
\end{tabular}


DISADVANTAGES OF EVALUATION OF HUMAN CAPITAL

$>$ Companies use various HRA models to compare two companies using two different models is quite difficult.

$>$ Companies could also misuse HRA to establish and enhance their image. A company can use this image in making goodwill in the investors mind, and change presumption to keep the values positive.

$>$ The model normally based on assumptions and which is subjective by nature; therefore figures can be totally ambiguous.

$>$ HRA does not show the true capacities of the employees towards the organization.

\section{METHODS OF HUMAN RESORCE ACCOUNTING}

\begin{tabular}{|l|}
\hline Historical cost method \\
\hline Replacement cost method \\
\hline Opportunity cost method \\
\hline Capitalization if salary method \\
\hline Economic valuation method \\
\hline Return on efforts employed method \\
\hline Adjusted discounted future wages method \\
\hline Reward valuation method \\
\hline Standard cost method \\
\hline Currant purchasing power method \\
\hline
\end{tabular}

\section{HISTORICAL COST METHOD}

This method developed by Brummet, Flamholtz and Pyle. According to this method, the actual cost incurred on recruiting, selecting, training, placing and developing the human resources of an enterprise are capitalized and written off over the expected useful life of human resources. The procedure followed for human resource asset is the same as that of other physical asset.

\section{REPLACEMENT COST METHOD}

This method was developed by Rensis Likert and Eric G. Flamholtz. The cost of replacing employees is used as the measure of company's human resources. The human resources of a company are to be valued on the assumptions as to what it will cost the concern if existing human resources are required to be replaced with other persons of equivalent experience and talent.

\section{OPPORTUNITY COST METHOD}

In order to overcome the limitations of replacement cost method, Hekimian and Jones suggested the use of opportunity cost method which determines the value of human resource on the basis of an employee's value in alternative uses.

\section{CAPITALIZATION OF SALARY METHOD}

The advocates of this method Baruch Lev and Schwartz have used the concept of human resources in term of economic value in this model. According to them the salaries payable to employees during their stay with the organization may be used as a replacement for the value of human resources, in view of the close co-relation between employees' compensation and their value to the organization. Thus the value of human resources is the present value of future earnings of homogeneous group of employees.

\section{ECONOMIC VALUATION METHOD}

It considers the present worth of the employee's future service expected to be derived during their stay with the organization as the value of firm's human resource. Although there are some resemblances between earlier model i.e., capitalization of salary method and this model, yet they differ with each other. The economic valuation model recommends the capitalization.

\section{RETURN ON EFFORTS EMPLOYED METHOD}

This method measures the value of the firm's human resources on the basis of efforts made by the individual for the organizational benefits. These efforts are evaluated in the light of the following factors:

$>$ Positions an employee holds;

$>$ Degree of excellence employee achieves;

$>$ Experience profile of the employee.

\section{ADJUSTED DISCOUNTED FUTURE WAGES METHOD}

Roger H. Hermanson developed this model wherein he recommends measuring the value of human resources on the basis of relative efficiency of an organization in the industry. This model relates the value of human resources with the extra profit the firm earns over and above the industry expectations.

\section{REWARD VALUATION METHOD}

As an improvement over the capitalization of salary method Flamholtz developed a model commonly known as Stochastic Rewards Valuation Method. The method seeks to measure the value of human resources on the basis of an employee's value to an organization at various services states that he is expected to occupy during the span of his working life with the organization.

\section{STANDARD COST METHOD}

This method envisages establishment of a standard cost per grade of employee, updated every year. Variances produced should be analysed and would form a useful basis for control. Replacement costs can be used to develop standard costs of recruitment, training and developing individuals, such standards can be used to compare actual results with those planned.

\section{CURRENT PURCHASING POWER METHOD}

Under it, instead of taking the replacement cost to capitalized, the capitalized historic cost of investment in human resources is converted into current purchasing power of money with help of index numbers. Its great advantage is its simplicity even though it might produce only approximate answers and approximate answers and approximately correct data.

\section{CHALLENGES OF HUMAN RESOURCE ACCOUNTING}

The problems of HRA rest majorly on the reporting companies themselves. The main obstacle to reporting human capital externally are as follows:

$>$ The information reported could be sensitive and the reporting companies may regard it as something that should not be shared externally, as it may give important insight to competitors or could lead to a negative interpretation on the part of the various stakeholders.

$>$ Companies do not attach first priority to the measurement of human assets, rather they focus on issues that they regard as more urgent like human resource requirement and allocation.

$>$ Where the human resource manager does not attach importance to the concept of HRA, the senior 
management will accord it even less importance and resources, leaving no time for measurement.

$>$ Managers think that the formal establishment of indicators of performance hardly adds any value to the external stakeholders. In other words, there is no return observed by many managers on the investment and effort required in reporting the human capital.

$>$ Another disincentive to the acceptance of HRA is the lack of universal approach to its reporting, thereby defining the standards that would allow for valuable and meaningful comparisons. Because there is a current absence of universal definition, the companies that are proactive enough to measure, do it 'their way'.

\section{CONCLUSION}

Human resource accounting helps for continuous improvement, effectiveness and efficiencies of management within an organization. This study is very very useful for the research scholars and others for identification and proper utilization and allocation of human resource in an organization. Most of the organization wants to develop diversity, renew and change, improve which require efficient employees. So the competencies and capabilities of the employees can be developed through effective human resource policies and practices. Human resources appear to be important to Indian organization do not value their human resources and plans to implement valuation of human resources are at a very early stage. While valuing human resources, importance can be given on acquisition costs, substitution costs, opportunity costs, replacement costs, economic value models standard cost method, nonmonetary measures etc.

There are no accurate evaluation measures to value the human resources however, by measuring these intangibles even though imprecise. It will help improved decision making on evaluating the value of the firm. It can be concluded that self development, Skill development and self evaluation are good practices for individual performance. Hence this study aims at finding out the impact of HRA model and effectiveness of HR policies and practices in management programs.

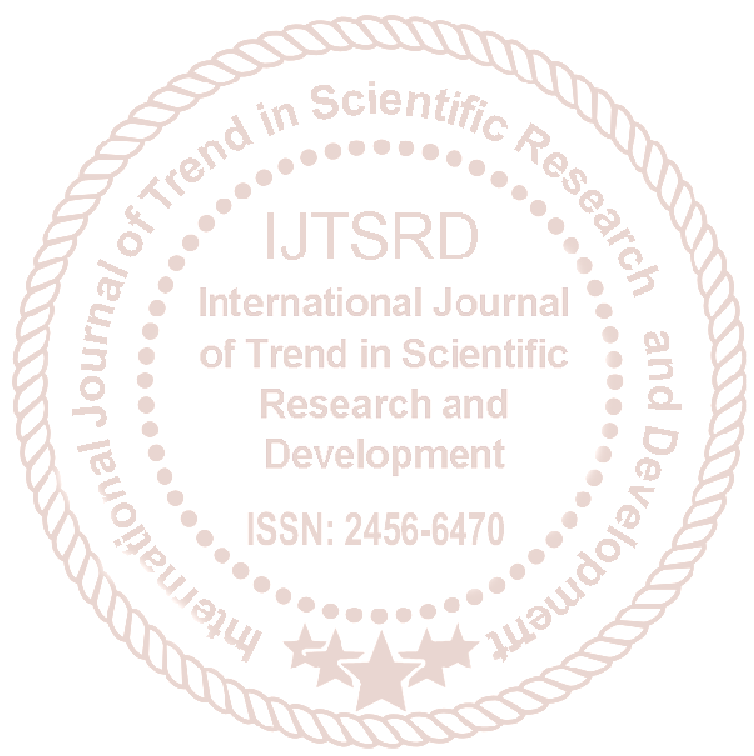

